\title{
EFFECTS OF SEASON AND STAGE OF LACTATION ON PROTEIN BOUND IODINE AND TOTAL CHOLESTEROL IN SERUM OF DAIRY COWS
}

\author{
VAPPU Kossila \\ Department of Animal Husbandry, University of Helsinki
}

Received May 30, 1963

Although the feeds of dairy cows do not usually contain cholesterol, yet their serum may contain considerable amounts of it. Thus it is evident that most of the cholesterol occurring in the serum is formed within the animal body, a great majority of it most probably in the liver. The changes in the amounts of different lipid fractions in the serum of dairy cows are usually parallel. In 1944, SAARINEN (22) found that among the different lipid fractions, the cholesterol fatty acid esters of plasma of dairy cows correlated best with their milk and milk fat yield. Combining the results from 12 feeding trials conducted during the years 1939-1952 he further found that several dietary factors influenced the plasma cholesterol content. Energy overfeeding had a positive influence on the plasma cholesterol level, and both the digestible crude fat and digestible crude fiber content of the ration showed statistically significant positive partial correlations to the plasma cholesterol level (23). On the other hand, energy overfeeding had a negative influence or none at all on the milk and milk fat yield of dairy cows, whereas the digestible crude fibre and digestible crude fat intake had a positive influence on these yields (24).

Several studies have shown that the metabolism of lipids in the liver is a affected by certain hormones such as those of anterior pituitary, adrenal cortex, and thyroid gland (3, p. 276). According to SAARINEN (24) variable amounts of estrogens did not appreciably affect the plasma cholesterol level of healthy lactating dairy cows. Likewise, in the experiments of the author (unpublished), even large doses of Астн, DocA, and cortisone injected into the cows had no significant effect on the plasma cholesterol level, and Астн was the only hormone which influenced secretion of milk, decreasing it very sharply with a simultaneous increase in fat percentage. It has been assumed that АстH exerts via the adrenal cortex an inhibiting influence upon the thyroid gland. Thyroid hormones, on the other hand, most likely play a very important part in milk and milk fat production. It has 
been noted in numerous experiments that substances with thyroxine-like activity in sufficient amounts increase both milk and milk fat yield of dairy cows $(30,31,32)$, and if the thyroid gland is removed from a healthy lactating cow, a very sharp decrease in milk secretion results (29). It is possible that insufficient thyroid function is one of the reasons for low milk production.

The purpose of this investigation was to study the influence of the season, the stage of lactation and the intensity of milk production upon protein bound iodine (PBI) and total cholesterol levels in the serum of healthy dairy cows under ordinary circumstances.

\section{Experimental}

The investigation included 92 healthy Ayrshire cows from which 589 blood samples were taken at different stages of lactation $(1,3,5,7,9,11$ and 13 months post partum) during a period of 18 months. Blood samples were collected between 4 and 6 p.m. from A. coccygea by the method described by SAarinen (21). To avoid impurities no anticoagulant was used. Total serum cholesterol was determined by method of SAARINEN (25) and serum protein bound iodine (PBI) was determined by the method of BARKER et al. (2). All determinations were carried out in duplicate.

The cows were fed approximately corresponding to their energy requirements without individual feed consumption control. During the indoor feeding period all the cows received timothy-clover hay (ad libtum) and calcifor-silage 10-11 $\mathrm{kg} /$ day. In addition, they were given swedes, brewer's grains, molasses-beet pulp and concentrates corresponding to their energy requirements. The approximate composition of the concentrate mixture was: oatmeal and wheat bran in the ratio $2: 1$, high-protein concentrates $15 \%$, and mineral mixture $8 \%$. Further, cows were given $50 \mathrm{~g}$ cod liver oil daily during one month pre and post partum. During the outdoor feeding period, which in Finland starts approximately on May 20 and ends on September 15, the cows consumed good-quality pasture grass ad libitum and, in addition, the higher-producing cows were given $1-4 \mathrm{~kg}$ of low-protein concentrate according to their daily milk production. During the outdoor feeding period, all the cows received trace mineral salt containing magnesium. The cows, which belonged to the University farm, had a better than average condition and level of production. They were milked twice a day by machine.

\section{Results}

In 589 serum samples of healthy dairy cows, cholesterol values varied from 37.6 to $494.4 \mathrm{mg} \%$, with approximately $66 \%$ of the cases falling between 100 and $300 \mathrm{mg} \%$. PBI values varied from 2.10 to $6.29 \gamma \%$, with approximately $79 \%$ of cases between 3 and $5 \gamma \%$.

Stage of lactation. The average total cholesterol and PBI levels in the serum of dairy cows, fat-corrected $(4 \%)$ daily milk production and the number of cases 
Table 1. Average total cholesterol and PBI levels at different stages of the lactation period

\begin{tabular}{ccccc}
\hline $\begin{array}{c}\text { Number of } \\
\text { cases }\end{array}$ & $\begin{array}{c}\text { Months post } \\
\text { partum }\end{array}$ & $\begin{array}{c}\text { Daily milk pro- } \\
\text { duction kg }\end{array}$ & $\begin{array}{c}\text { Total choles- } \\
\text { terol mg } \%\end{array}$ & $\begin{array}{c}\text { PBI } \\
\gamma\end{array}$ \\
\hline 111 & 1 & 24.6 & $177 \pm 7.87$ & $3.65 \pm 0.08$ \\
88 & 3 & 20.9 & $267 \pm 9.67$ & $3.85 \pm 0.09$ \\
98 & 5 & 18.4 & $245 \pm 8.57$ & $4.11 \pm 0.08$ \\
89 & 7 & 15.8 & $229 \pm 9.57$ & $3.99 \pm 0.07$ \\
87 & 11 & 13.2 & $186 \pm 8.69$ & $4.04 \pm 0.09$ \\
85 & 13 & 7.5 & $120 \pm 6.25$ & $3.96 \pm 0.08$ \\
31 & & 1.6 & $77 \pm 7.44$ & $4.08 \pm 0.17$ \\
\hline
\end{tabular}

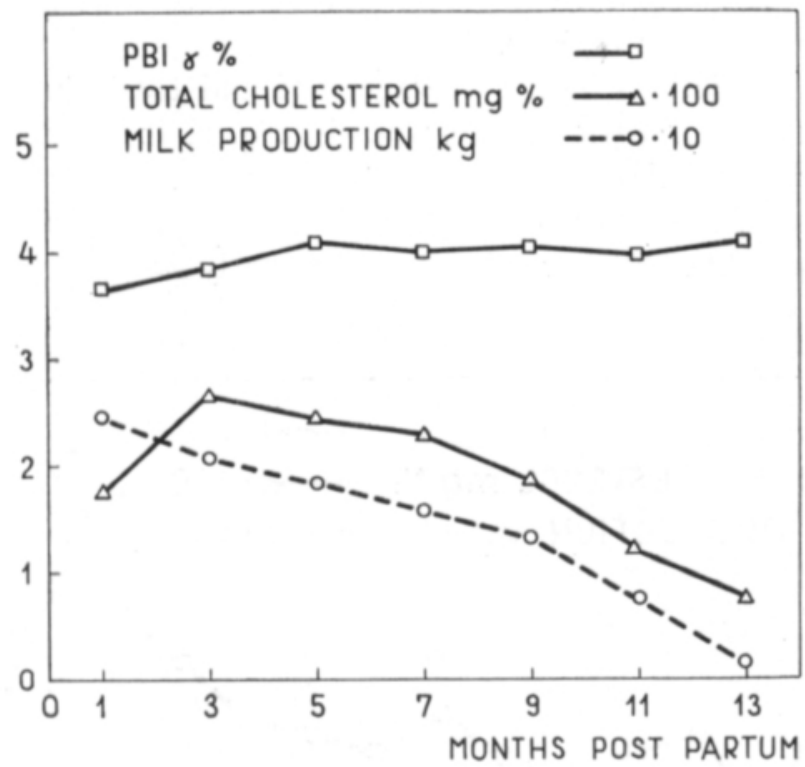

Fig. 1. Vartiations of PBI and total cholesterol levels in the serum as well as average daily milk production of cows in different stages of lactation.

at different stages of lactation are presented in Table 1. Variations in the average PBI and cholesterol levels at different stages of lactation compared with milk production are illustrated with graphs in Fig. 1. There was a slight rise in the average PBI level from the first to fifth month, while in the later stages of lactation the PBI level remained rather constant. The average total cholesterol level was relatively low one month post partum, reaching its maximum 3 months p.p., after which it declined towards the later stages of lactation period, with minimum levels occurring during the dry period. Most of the cows at the stage of 13 months p.p. were dry. 
Seasonal variations. The monthly averages of total cholesterol and PBI levels of serum, the average daily milk production as well as the number of cows in different stages of lactation during the investigation period are presented in Table 2. It shows that the PBI level was highest during the spring months (April, May, June) and distintcly declined in the late summer months (July, August). In 1958 the minimum PBI level was reached in July and in 1959 in August. The PBI level rose in late summer and remained rather constant from September to March, with the exception of December, during which PBI level showed a slight rise.

The highest monthly averages in total cholesterol values appeared during the indoor feeding period (from December 1958 to May 1959), and the lowest values during the pasture feeding period. From May towards the late summer months, the cholesterol level declined very distinctly. In the late summer, cholesterol values had a tendency to increase. During the fall indoor feeding period (September, October, November) the average cholesterol values were somewhat higher than those obtained during the outdoor feeding period but were definitely lower than those obtained during December to May.

The seasonal variations in the average PBI and total cholesterol levels and in milk production are illustrated by graphs in Fig. 2. It shows that the seasonal variations of PBI and cholesterol levels closely resemble one another. The high average milk production occurring in May and June, 1959, was dependent to a certain degree upon the number of cows in the early stages of lactation (Table 2).

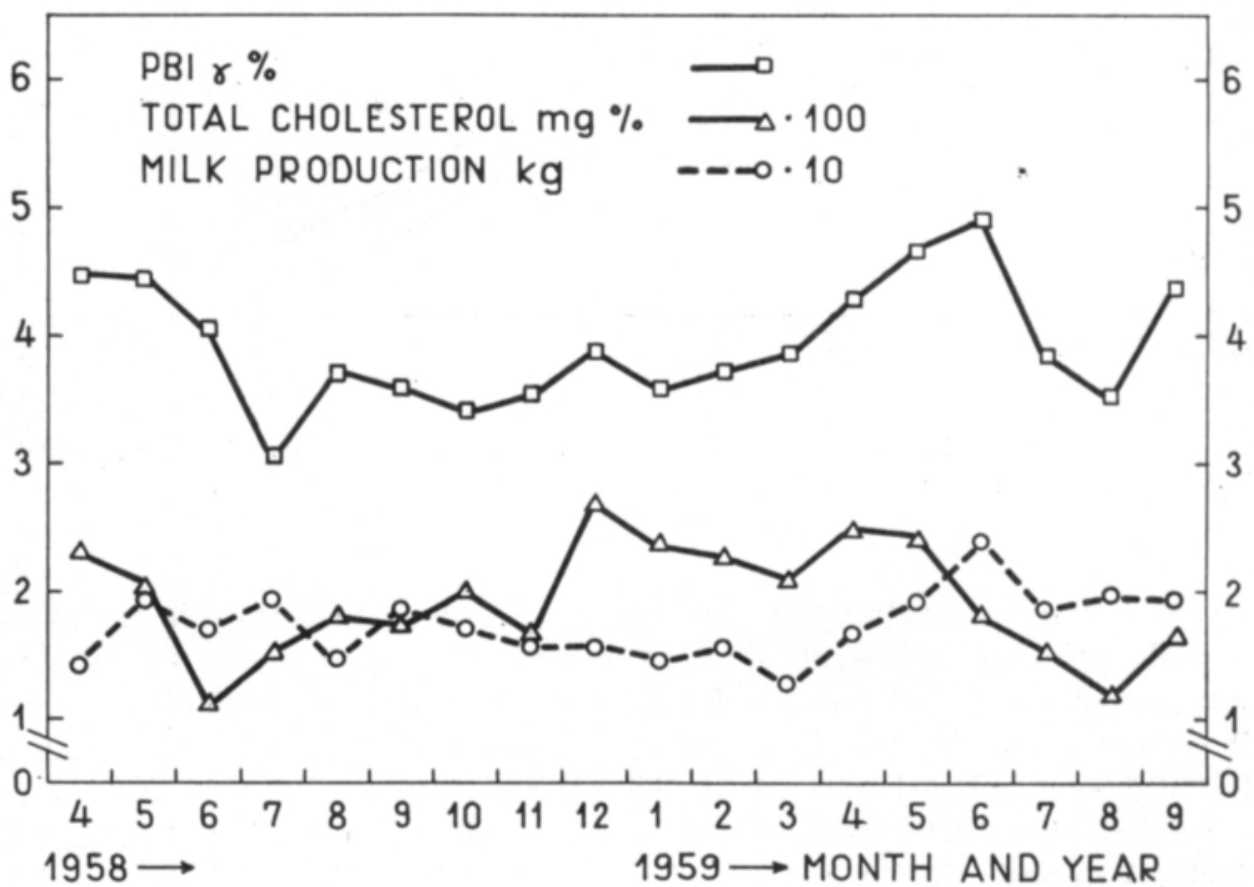

Fig. 2. Seasonal variations of PBI and total cholesterol levels in the serum as well as average daily milk production of cows during the investigation period. 
Table 2. The number of cows at different stages of lactation, the average PBI and total cholesterol levels in serum, and the average fat-corrected $(4 \%)$ daily milk production $\mathrm{kg}$ of cows in each month of the investigation period.

\begin{tabular}{|c|c|c|c|c|c|c|c|c|c|c|c|}
\hline \multirow{2}{*}{$\begin{array}{c}\text { Year } \\
\text { and } \\
\text { month } \\
1958\end{array}$} & \multicolumn{7}{|c|}{$\begin{array}{l}\text { Number of cows at different stages } \\
\text { of lactation (months post partum) }\end{array}$} & \multirow{2}{*}{$\begin{array}{l}\text { Number } \\
\text { of cases } \\
\text { in each } \\
\text { month }\end{array}$} & \multicolumn{2}{|c|}{ Serum levels } & \multirow{2}{*}{$\begin{array}{c}\text { Daily } \\
\text { milk } \\
\text { produc- } \\
\text { tion kg }\end{array}$} \\
\hline & 1 & 3 & 5 & 7 & 9 & 11 & 13 & & PBI $\gamma \%$ & $\begin{array}{l}\text { Total choles- } \\
\text { terol mg } \%\end{array}$ & \\
\hline 4 & 2 & 6 & 5 & 7 & 5 & 8 & - & 33 & $4.49 \pm 0.15$ & $230.5 \pm 16.25$ & 14.09 \\
\hline 5 & 6 & 5 & 6 & 1 & 12 & 5 & - & 35 & $4.46 \pm 0.10$ & $206.5 \pm 15.61$ & 19.16 \\
\hline 6 & 6 & 4 & 6 & 5 & 2 & 4 & - & 27 & $4.09 \pm 0.12$ & $111.4 \pm 8.08$ & 17.09 \\
\hline 7 & 8 & 4 & 3 & 3 & 1 & 11 & - & 30 & $3.07 \pm 0.10$ & $153.5 \pm 8.29$ & 19.36 \\
\hline 8 & 5 & 7 & 4 & 8 & 5 & 4 & - & 33 & $3.72 \pm 0.11$ & $180.9 \pm 12.86$ & 14.52 \\
\hline 9 & 11 & 9 & 5 & 4 & 4 & 2 & - & 35 & $3.58 \pm 0.11$ & $175.3 \pm 12.00$ & 18.20 \\
\hline 10 & 4 & 3 & 5 & 3 & 3 & 2 & - & 20 & $3.42 \pm 0.10$ & $199.3 \pm 13.84$ & 16.90 \\
\hline 11 & 4 & 9 & 7 & 4 & 5 & 5 & - & 34 & $3.53 \pm 0.11$ & $166.2 \pm 13.42$ & 15.79 \\
\hline 12 & 3 & 7 & 5 & 6 & 2 & 2 & - & 25 & $3.88 \pm 0.12$ & $268.0 \pm 19.14$ & 15.79 \\
\hline \multicolumn{12}{|l|}{1959} \\
\hline 1 & 8 & 6 & 9 & 8 & 5 & 6 & 5 & 47 & $3.59 \pm 0.09$ & $237.1 \pm 16.73$ & 14.56 \\
\hline 2 & 4 & 2 & 8 & 7 & 6 & 4 & 2 & 33 & $3.73 \pm 0.09$ & $227.9 \pm 17.65$ & 15.51 \\
\hline 3 & 5 & 4 & - & 4 & 6 & 2 & 5 & 26 & $3.85 \pm 0.07$ & $209.6 \pm 21.84$ & 12.63 \\
\hline 4 & 10 & 6 & 6 & 10 & 7 & 8 & 4 & 51 & $4.28 \pm 0.11$ & $248.5 \pm 16.07$ & 16.63 \\
\hline 5 & 10 & 6 & 7 & 5 & 6 & 6 & 3 & 43 & $4.67 \pm 0.12$ & $242.4 \pm 16.72$ & 19.11 \\
\hline 6 & 10 & - & 2 & - & 5 & - & 1 & 18 & $4.91 \pm 0.19$ & $181.7 \pm 21.07$ & 23.80 \\
\hline 7 & 6 & 8 & 10 & 8 & 7 & 9 & 8 & 56 & $3.81 \pm 0.11$ & $155.9 \pm 9.88$ & 13.53 \\
\hline 8 & 7 & 2 & - & 2 & 1 & 3 & 2 & 17 & $3.51 \pm 0.10$ & $119.8 \pm 12.10$ & 14.61 \\
\hline 9 & - & - & 8 & 4 & 1 & 4 & 1 & 18 & $4.39 \pm 0.11$ & $167.7 \pm 16.69$ & 14.46 \\
\hline
\end{tabular}

Total $\quad 581$

Individual factors. A few examples of the maximum and minimum levels of PBI and total cholesterol in the serum of individual cows during the investigation period are given in the following compilation.

Cow Number of PBI $\gamma \% \quad$ Total cholesterol $\mathrm{mg} \%$ No. samples Minimum Maximum Minimum Maximum

$\begin{array}{rrrrrr}7 & 9 & 2.3 & 3.8 & 38.4 & 115.9 \\ 47 & 9 & 2.9 & 4.4 & 37.6 & 372.0 \\ 22 & 10 & 3.4 & 5.4 & 87.8 & 411.5 \\ 60 & 8 & 3.3 & 5.6 & 110.2 & 401.3 \\ 90 & 9 & 3.7 & 6.1 & 59.5 & 306.7\end{array}$

As can be seen, rather distinct individual characteristics exist especially in the PBI level of different cows. The differences between the maximum and minimum levels in individual cases are more noticeable in total cholesterol than in PBI. The cows in the above sampling had been under investigation at least during one complete lactation period and were thus once dry while blood samples were taken. 


\section{Discussion}

The PBI levels obtained in the serum of healthy cows in this study indicate neither hyper- nor hypothyroidism, and they agree well with several results obtained with dairy breeds elsewhere $(8,11,12,28)$. Actually, the PBI level in serum may not be as good an indicator of activity of the thyroid gland as some other tests, for instance the thyroid secretion rate measured by the method of MIXNER \& LENNON (16) or by the method of Premachandra \& Turner (17). The PBI level merely reflects the balance between the hormone secretion rate from the thyroid gland and the rate of disappearance of the hormone from the blood. In other words, the PBI level indicates, whether or not the thyroid gland is able to maintain an optimal PBI level in the blood.

Table 1 and Fig. 1 show that both the PBI and total cholesterol levels in serum are relatively low during one month post partum; yet the average daily milk production indicates that the metabolism rate of the cow should be at its maximum at this moment. Relatively low PBI values at the peak of milk production may occur, because the catabolism of the thyroid hormones in the organism is somewhat faster than their synthesis within the thyroid gland. Another explanation is that a possible stress caused by high production reflects its influence through other endocrine factors, e.g. pituitary gland and adrenal cortex, upon the thyroid gland. In fact, several studies have shown that stress conditions tend to depress plasma PBI level $(9,10,19)$. On the basis of the results of Mixner et al. (15) the firstmentioned explanation seems to be more natural in this case. The above authors found that the thyroid secretion rate was faster at the early stages of lactation than later, even though the PBI level was lowest at the early stages. In some cases temporary shortage of iodine during the period increasing milk production may also influence the thyroid secretion rate and PBI level in the serum of ruminants $(6,18)$.

Relatively low cholesterol levels at the peak of lactation, i.e. one month post partum, may be caused by physiological undernutrition, which is known to have a depressing effect on the plasma cholesterol level (26). Presumably, relatively low PBI and cholesterol levels occurring shortly after parturition indicate to a certain degree that the functions of the rumen and liver as well as the rate of hormone formation within the thyroid gland need a certain period of time to adapt themselves gradually to the faster metabolism rate required by increased milk production.

As Fig. 1 shows, in the later stages of lactation, from the 5th to 13 th months post partum, the PBI level remained rather constant, which indicates that the thyroid gland was able to supply enough hormone for the optimum requirements of the body. The total cholesterol level, on the other hand, decreased from the 3rd to 13th month paralleling the daily average milk production. Assuming that the cholesterol level in cow serum indicates the intensity of liver activity and that the fatty acids of the cholesterol esters in the serum participate in milk fat formation, it is quite understandable that the cholesterol level decreases with decreasing milk production. It is possible that some hormones related to the secretion of milk 
participate also in keeping the cholesterol level relatively high during the lactation period. The possible influence of pregancy in the later stages of lactation has not yet been taken into consideration in this investigation.

Table 2 and Fig. 2 show that there are distinct seasonal changes in both PBI and cholesterol values, which also are guite similar in pattern. It is evident that there are common factors, e.g. feeding patterns, exercise, environmental temperature and fluctuations of plasma volume, which effect simultaneously PBI and cholesterol levels either lowering or raising them. Presumably there are factors, e.g. light, which may affect the thyroid activity and PBI level of serum, but likely have no influence on the cholesterol level. Correspondingly there may be factors influencing the cholesterol level independently of the PBI level. Since the factors mentioned above may differ from year to year, it is easy to understand that the results obtained in different years may not agree with each other. This explains at least to a certain degree the controversial results reported in the literature. To eliminate individual effects, it would have been desirable to have more blood samples analysed in each month of the investigation period.

In pathological conditions of the thyroid gland, low cholesterol values are often seen in cases of hyperthyroidism and high cholesterol values in cases of hypothyroidism. However, this does not seem to be true in the case of normal lactating dairy cows. Cholesterol values often exceeding $350 \mathrm{mg} \%$ and in some cases $450 \mathrm{mg} \%$ noted in the present investigation in the serum of healthy lactating cows did not indicate hypothyroidism, when thyroid activity was judged by the PBI level of serum. The partial correlations between $4 \%$ fat-corrected daily milk production $\mathrm{kg}\left(\mathrm{X}_{1}\right)$, total cholesterol $\mathrm{mg} \%\left(\mathrm{X}_{2}\right)$, and PBI level $\gamma \%\left(\mathrm{X}_{3}\right)$ obtained from individual cases in different stages of lactation were positive. The correlations obtained 3 and 5 months post partum $\left(\mathrm{r}_{23 \cdot 1}=+0.33\right.$ and +0.31 respectively) deviated significantly from zero at the level of $\mathrm{P}<0.005$ and 7 months post partum $\left(\mathrm{r}_{23 \cdot 1}=+0.22\right)$ at the level of $\mathrm{P}<0.05$. These results, which will be published later in greater detail, indicate that thyroid hormones may even participate in maintaining a high cholesterol level during the lactation period of healthy dairy cows.

It is possible that parallel seasonal variations in PBI and cholesterol levels (Fig. 2) may have had a favorable influence in obtaining significant positive correlations between $\mathrm{X}_{2}$ and $\mathrm{X}_{3}$ in the above-mentioned cases. Complete elimination of seasonal effects may diminish the above correlations but likely not change them to negative. If the thyroid secretion rate would have been used as an indicator of thyroid activity instead of serum PBI, the correlations between the thyroid secretion rate and the level of cholesterol in the plasma might have been even more significantly positive than they were in present investigation. The thyroid secretion rate declines with decreasing milk production (15). Thyroid hormones may influence the quality and quantity of volatile fatty acids formed in the rumen (1). These, in turn, affect the functions of the liver (27). Thyroid hormones are needed for acetoacetate synthesis in the liver (3, p. 276), and acetoacetate is an important precursor of cholesterol. Further, thyroid hormones stimulate the rate of conversion of cholesterol to bile acids (33). The rate of cholesterol synthesis (14) as 
well as the rate of cholesterol destruction and intestinal excretion (20) are increased during hyperthyroidism. Thus there seem to be several ways by which the thyroid hormones may influence the cholesterol content in serum. Thyroactive substances given to lactating cows reduce the cholesterol content in their serum, but after prolonged use, the organism becomes accustomed to the effect and the cholesterol concentration has a tendency to return to the initial level (13). Thus the healthy lactating cow most likely needs a proper functioining thyroid gland for keeping the serum lipids at a level which is most desirable for milk production. There are certain dietary factors that affect the level of serum cholesterol, however, this may be a result of their influence on the thyroid activity. The results obtained in hypo- or hyperthyroid conditions cannot be applied as such to healthy conditions. Also, the cholesterol in the serum of cows is transported mainly in the form of $\alpha$ lipoprotein. The amount of $\beta$-lipoprotein in very low $(4,5)$. High levels of $\beta$-lipoprotein cholesterol in nonruminants are associated with such pathological conditions as artheriosclerosis (7). Although cows may show cholesterol values exceeding $400 \mathrm{mg} \%$, they do not seem to be harmed by it possibly because the cholesterol in their serum is in the form of a-lipoprotein.

\section{$S u m m$ ary}

Protein bound iodine (PBI) and total cholesterol levels in serum were determined from 589 arterial samples of healthy dairy cows in different stages of lactation during a period of 18 months. PBI values varied from 2.10 to $6.29 \gamma \%$, with approximately $79 \%$ of the cases occurring between 3 and $5 \gamma \%$ and the average PBI level being $3.935 \gamma \%$. Cholesterol values varied from 37.6 to $494.4 \mathrm{mg} \%$, with approximately $66 \%$ of the cases between 100 and $300 \mathrm{mg} \%$ and the average colesterol level being $197.43 \mathrm{mg} \%$.

The stage of lactation had a greater influence on total cholesterol level than on PBI level. PBI level was lowest one month post partum $(3.65 \pm 0.08 \gamma \%)$, but remained rather constant from the 5th to 13 th month post partum, varying between $3.96 \pm 0.08$ and $4.11 \pm 0.08 \gamma \%$. It was assumed that during the early stages of lactation the disappearance of thyroid hormones from the serum may be somewhat faster than their synthesis within the thyroid gland, and after an adaptation period in the later stages of lactation, the thyroid gland is able to maintain an optimal PBI level in the serum.

The average cholesterol level of $177 \mathrm{mg} \%$ one month post partum was relatively low in regard to milk production compared with cholesterol levels obtained at later stages of lactation. The relatively low cholesterol values in the early part of lactation may have reflected a state of physiological undernutrition or an adaptation of the liver and rumen to increasing milk production. The total cholesterol was parallel with milk production from the 3rd to 13 th month post partum. The lowest cholesterol values occurred in the serum of dry cows.

Significant seasonal variations were noticed in PBI and cholesterol levels. The highest average PBI levels were obtained in April, May, and June and the 
lowest at the end of July and at the beginning of August. The cholesterol levels were highest during the indoor feeding period from December to May and lowest during the pasture feeding period. Since seasonal variations of total cholesterol level resembled greatly those of PBI, it was assumed that there are common factors influencing simultaneously both the PBI and cholesterol levels.

\section{REFERENCES}

(1) Azrmov, G. I. 1962. The thyroid, the processes in the rumen and the fat content of milk. Int. Dairy Congr., Copenhagen 1962, A 112-118.

(2) Barker, S. B., Humphrey, M. J. \& Soley, M. H. 1951. The clinical determination of protein bound iodine (PBI). J. Clin. Invest. 30: 55 .

(3) BLoch, K. 1960. Lipide metabolism. XIII + 411 pp. New York.

(4) Campbell, E. A. 1963. The serum lipoproteins of the domestic animals. Res. vet. Sci. 4: $56-63$.

(5) Evans, L., Patton, S. \& McCarthy, R. D. 1961. Fatty acid composition of the lipid fractions from bovine serum lipoproteins. J. Dairy Sci. 44: 475-481.

(6) Flamboe, E. E. \& Reinecke, E. P. 1959. Estimation of thyroid secretion rates in dairy goats and measurement of $\mathrm{I}^{131}$ uptake and release with regard to age, pregnancy, lactation, and season of the year. J. Anim. Sci. 18: 1135.

(7) Keys, A., Karvonen, M. J. \& Fidanza, F. 1958. Serum cholesterol studies in Finland. Lancet ii, 175 .

(8) Lennon, H. D. \& Mixner, J. P. 1957. Variation in PBI level in dairy cattle due to animal, daily, diurnal and method effects. J. Dairy Sci. 40: 541-545.

(9) - -1957 . Some sources of variation in total plasma cholesterol levels in dairy cattle. Ibid. 40: 1424 .

(10) Lewis, R. C. \& Ralston, N. P. 1952. Plasma PBI changes in new-born calves. J. Anim. Sci. 11: 796 .

(11) - -1953 . PBI levels in dairy cattle plasma. J. Dairy Sci. 33: 36.

(12) Long, J. F., GiLmore, L. O. et al. 1951. The bovine PBI as related to age, sex, and breed. J. Anim. Sci. 10: 1027.

(13) Long, J. F., HibBs, J. W. \& Gilmore, L. O. 1953. The effect of thyroprotein feeding on the blood level of inorganic iodine, PBI, and cholesterol in dairy cows. J. Dairy Sci. 36: 1049.

(14) Marx, W., Gustin, S. T. \& Levi, C. 1953. Effects of thyroxine, thyroidectomy and lowered environmental temperature on incorporation of deuterium into cholesterol. Proc. Soc. Exptl. Biol. Med. 83: 143.

(15) Mixner, J. P. 1961. The effects of breed, stage of lactation, and season of year on thyroid secretion rate in dairy cows as determined by the chemical turnover method. J. Dairy Sci. 44: 1194.

(16) - - \& LENnon, H. D. 1959. Thyroxine secretion rates in dairy cattle as calculated from plasma levels, turnover rates and volumes of distribution of thyroxine. Int. Dairy Congr. 1: $20-26$.

(17) Premachandra, B. N., Pipes, G. W. \& Turner, C. W. 1960. Thyroxine secretion rate of cattle utilizing radioactive iodine $\left(\mathrm{I}^{131}\right)$ as a tracer. Mo. Agr. Exp. Sta. Res. Bull. 727.

(18) ReIneKe, E. P. 1961. Factors affecting the secretion of $\mathrm{I}^{131}$ into milk of lactating goats. J. Dairy Sci. 44: 937.

(19) Robertson, W. G., Lennon, H. G. et al. 1957. Interrelationships among plasma 17-hydroxycorticosteroid levels, plasma-PBI-levels and ketosis in dairy cattle. Ibid. 40: 732.

(20) Rosenman, R. H., Byers, S. O. \& Friedman, M. 1952. The mechanism responsible for the altered blood cholesterol content in deranged thyroid states. J. Clin. Endocrinol. Metabolism 12: 1287. 
(21) SaArinen, P. 1938. Einfaches Verfahren zur Gewinnung von Arterieblutproben beim Rindwieh. J. Sci. Agric. Soc. Finland. 10: 140.

(22) - - 1944. Lehmän veriplasman eräiden lipoidiaineosien vaikutuksesta maitorasvan muodostukseen. Acta Agralia Fennica. 57: (2): 1-131.

(23) - - 1955. Diet and plasma cholesterol in dairy cows. J. Sci. Agric. Soc. Finland. 27: 117-141.

(24) - - 1959. "Cholesterogenic dietary factors and milk and milk fat yields in dairy cows. Ibid. 31: $1-10$.

(25) - - \& Shaw, J. C. 1950. Studies on ketosis in dairy cattle. XI. Lipids, minerals and ascorbic acid in the blood of cows with spontaneous ketosis. J. Dairy Sci. 33: 496-507.

(26) - -1950 . Studies on ketosis in dairy cattle. XII. Blood lipids, phosphatases and phosphatase activity of cows on different levels of feed intake post partum. Ibid. 33: 508-514.

(27) Shaw, J. C. 1959. Nutritional physiology of the rumen, a new approach to rumen nutrition. Feedstuffs. Sept. 12. Vol. 31.

(28) Sørensen, P. H. 1958. Jodstofskifte og thyreoideafunction hos kvaeg og svin. 302. Beretning fra Forsøgslab. Copenhagen.

(29) Spielman, A. A., Petersen, W. E. \& Fitch, J. B. 1944. The effect of thyroidectomy on lactation in the bovine. J. Dairy Sci. 27: 441.

(30) Swanson, E. W. 1957. Effects of feeding thyroxine or thyroprotein to identical-twin dairy cows for successive lactations. Ibid. 40: 1391.

(31) $-\quad \&$ Miller, W. M. 1957. Three lactations of feeding thyroxine with indentical twin cows. J. Anim. Sci. 16: 1060.

(32) Turner, C. W., Yamamoto, H. \& Ruppert, H. L. 1957. Endocrine factors influencing the intensity of milk secretion. Estrogen, thyroxine and growth hormone. J. Dairy Sci. 40: 37.

(33) Weiss, S. B. \& MARX, W. 1955. The fate of radioactive cholesterol in mice with modified thyroid activities. J. Biol. Chem. 213: 349.

\title{
SELOSTUS:
}

VUODENAJAN JA LAKTAATIOKAUDEN VAIHEEN VAIKUTUKSESTA VERISEERUMIN PROTEINIIN SIDOTUN JODIN JA KOKONAISKOLESTEROLIN MÄÅRIIN LYPSYLEHMILLÅ

\author{
VAPPU Kossila \\ Helsingin yliopisto, Kotieläintieteen laitos
}

Terveiden, laktaatiokauden eri vaiheissa (1, 3, 5, 7, 9, 11 ja 13 kk poikimisesta) olleiden Ayrshire rotuisten lehmien veriseerumin proteiniin sidotun jodin (PBI) ja kokonaiskolesterolin konsentraatiot määritettiin 589 valtimoverinäytteestä $18 \mathrm{kk}: \mathrm{n}$ aikana.

PBI-arvot vaihtelivat $2.10-6.29 \gamma \%$ ja noin $79 \%$ tapauksista oli $3-5 \gamma \%$ :n välillä keskimääräisen PBI-tason ollessa $3.935 \gamma \%$.

Kolesteroliarvot vaihtelivat $37.6-494.4 \mathrm{mg} \%$ ja noin $66 \%$ tapauksista oli $100-300 \mathrm{mg} \%$ :n välillä keskimääräisen kolesterolitason ollessa $197.43 \mathrm{mg} \mathrm{\%}$.

Laktaatiokauden vaihe näytti vaikuttavan selvemmin kolesteroli- kuin PBI-tasoon. PBI-taso oli alhaisimmillaan $1 \mathrm{kk}$ poikimisesta pysytellen suhteellisen muuttumattomana 5 kk:sta laktaatiokauden loppuun. Laktaatiokauden alussa havaittujen suhteellisen alhaisten PBI-arvojen arveltiin johtuvan siitä, että kilpirauhashormonin katoaminen verestä olisi tällöin jonkinverran nopeampaa kuin niiden synteesi kilpirauhasessa, kun taas laktaatiokauden myöhemmissä vaiheissa kilpirauhanen pystyisi pitämään hormonimäärän veressä optimaalisena.

Veriseerumin kolesterolitaso oli päivittäiseen maidontuotantoon verrattuna suhteellisesti alhaisin 1 kk poikimisesta, ja mainitun ilmiön arveltiin kuvaavan fysiologista aliravitsemustilaa, joka saattaa 
ilmetä lehmillä etenkin juuri herumahuipun vaiheilla. 3 kk:sta laktaatiokauden loppuun kolesterolitaso muuttui samansuuntaisesti maitotuotoksen kanssa. Ummessaolevilla lehmillä tavattiin alhaisimmat kolesteroliarvot.

Kolesteroli- ja PBI-arvoissa havaittiin erittäin selviä vuodenajoista johtuvia vaihteluita. Korkeimmat kuukautiset keskiarvot PBI-tasossa tavattiin huhti-, touko- ja kesäkuussa ja alhaisimmat heinäelokuun vaihteessa. Korkeimmat kolesteroliarvot tavattiin sisäruokintakautena joulukuusta toukokuuhun ja alhaisimmat laidunkautena. Kolesteroli- ja PBI-tasojen vuodenaikaiset vaihtelut olivat useimmiten yhdensuuntaisia. Mainitun ilmiön arveltiin johtuvan siitä, että on olemassa sellaisia tekijöitä, kuten esim. liikunta, ympäristön lämpötilan vaihtelut, ruokinta ja plasmavolyymin muutokset, jotka vaikuttavat samanaikaisesti kolesteroli- ja PBI-tasoon joko kohottaen tai alentaen niitä. 